\title{
CONFESSIONS MADE AFTER DELAYED ARRAIGNMENT: MCNABB AGAIN*
}

WHEN unlawful police methods have been used to extract one confession from a defendant, the policies served by declaring that confession inadmissible at trial also require the examination of all subsequent confessions offered in evidence to make certain that they have not been induced by the continuing influence of prior police conduct. ${ }^{1}$ In the federal courts, confessions may be excluded for two reasons. Those acquired by third degree tactics are inadmissible under the due process clause because they are involuntary and untrustworthy. ${ }^{2}$ Once the use of third degree tactics has been proved, courts have circumscribed the admissibility of later confessions by erecting a rebuttable presumption that the influence of such tactics has continued and has tainted all subsequent statements. ${ }^{3}$ A confession may also be invalidated under the rule enunciated in $M c N a b b v$. United States, ${ }^{4}$ solely on the ground that it was

*Jackson v. United States, 273 F.2d 521 (D.C. Cir. 1959) ; Goldsmith v. United States, 277 F.2d 335 (D.C. Cir. 1960).

1. See Lyons v. Oklahoma, 322 U.S. 596, 606-07 (1944) (dissenting opinion); Note, 26 Texas L. Rev. 536, 538 (1948). But see Note, 33 Iowa L. Rev. 136, 139 (1947).

2. Professor Wigmore regards the possibility that a confession might be untrustworthy as the only valid reason for its exclusion. 3 WIGMORE, EvIDENCE $\$ 822$ (3d ed. 1940) [hereinafter cited as WIGMORE]. The Supreme Court has held that a confession must be voluntary and not induced by unfair police practices even though it might be reliable. See, e.g., Rochin v. California, 342 U.S. 165, 173 (1951); Lisenba v. California, 314 U.S. 219, 236 (1941). For the evolution of these two standards of admissibilitytrustworthiness and voluntariness-see Paulsen, The Fourteenth Amendment and the Third Degree, 6 Stan. L. REv. 411, 429 (1954); Maguire, "Involuntary" Confessions, 31 Tul. L. Rev. 125 (1956); Comment, 27 FordiaAr L. Rev. 396, 399 (1958).

Among the police methods which have caused exclusion are: the application of physical force, e.g. Brown v. Mississippi, 297 U.S. 278 (1936); threats of bodily harm, c.g., Malinski v. New York, 324 U.S. 401, 406 (1945); fear of mob violence, e.g., Ward v. Texas, 316 U.S. 547, 555 (1942) ; promises of leniency, e.g., State v. Moore, 210 N.C. 686, 188 S.E. 421 (1936); State v. Chiasson, 174 La. 542, 141 So. 54 (1932) ; 3 WIgurore $\$ \$$ 834-36; and prolonged continuous interrogation, e.g., Ashcraft v. Tennessee, 322 U.S. 143 (1944).

3. Cf. People v. Jones, 24 Cal. 2d 201, 209, 150 P.2d 801, 805 (1944); McCorarick, EvIDENCE \& 114 (1954). The prosecution must prove that the influence of coercion has terminated. Cf. Jackson v. State, 209 Md. 390, 394-95, 121 A.2d 242, $244-45$ (1956) ; State v. Hamer, 240 N.C. 85, 88, 81 S.E.2d 193, 195 (1954); 2 Wharton, Crininal Evidence $\S 359$, at 64 (12th ed. 1955) [hereinafter cited as WhARToN].

4. 318 U.S. 332 (1943).

Since the Federal Rules of Criminal Procedure had not been formulated at the time of the $M c N a b b$ decision, the Court relied on older federal statutes requiring prompt arraignment. $I d$. at 342 . Subsequently, confessions obtained by police while violating the provisions of Rule 5(a) have been excluded. See, e.g., Mallory v. United States, 354 U.S. 449 (1957) ; Upshaw v. United States, 335 U.S. 410 (1948). See generally Hogan \& Snee, The McNabb-Mallory Rule: Its Rise, Rationale and Rescue, 47 GEo. L.J. 1 
a product of illegal delay before arraignment in violation of Rule 5(a) of the Federal Rules of Criminal Procedure. ${ }^{5}$ Although courts applying this exclusionary rule have emphasized the likelihood that delayed detention will result in coercive police methods, ${ }^{6}$ the rule itself is not based on a finding that the confession was untrustworthy or involuntary $;^{7}$ indeed, no inquiry is made into these issues. ${ }^{8}$ Rather, the $M c N a b b$ rule is a per se rule of inadmissibility which the Supreme Court has constructed in order to deter Federal officers from using prearraignment detention as an investigating technique. ${ }^{9}$ Because the $M c N a b b$ rule is directed at police procedures rather than the effects of police procedures upon a particular confession, and thus serves a more general administrative purpose, the admissibility of confessions rendered after a first confession has been invalidated under $M c N a b b$ alone raises different and more complicated problems.

(1958); Inbau, The Confession Dilennna in the United States Supreme Court, 43 ILL. L. Rev. 442 (1948); Orfield, Proceedings Before the Commissioner in Federal Criminal Proccdure, 19 U. PitT. L. Rev. 489 (1958); Comment, 68 Yale L.J. 1003 (1959).

5. Appearance before the Commissioner.

An officer making an arrest under a warrant issued upon a complaint or any person making an arrest without a warrant shall take the arrested person without unnecessary delay before the nearest available commissioner or before any other nearby officer empowered to commit persons charged with offenses against the laws of the United States. When a person arrested without a warrant is brought before a commissioner or the officer, a complaint shall be filed forthwith.

FED. R. CRIMr. P. 5(a). The commissioner is required to advise the accused of his right to retain counsel, his privilege against self-incrimination and his right to a preliminary hearing to ascertain whether there is "probable cause to believe" that he committed a crime. FED. R. CRIM. P. 5(b), -(c).

6. MicNabb v. United States, 318 U.S. 332, 344 (1943) :

[T] his procedural requirement checks resort to those reprehensible practices known as the "third degree" which, though universally rejected as indefensible, still find their way into use. It aims to avoid all the evil implications of secret interrogation of persons accused of crime.

Mallory v. United States, 354 U.S. 449, 453 (1957) (In $M c N a b b$ "unwarranted detention led to tempting utilization of intensive interrogation, easily gliding into the evils of 'the third degree.' ") ; United States v. Carignan, 342 U.S. 36, 45 (1951) (Unlawful detention "was thought to give opportunity for improper pressure by police before the accused had the benefit of the statement by the commissioner.").

7. McNabb v. United States, 318 U.S. 332, 340 (1943) ("it becomes unnecessary to reach the Constitutional issue"). Compare United States v. Mitchell, 322 U.S. 65, 71 (1944) (Reed, J., concurring).

8. A finding that a confession obtained during a period of unlawful detention was voluntary and not induced by coercion is irrelevant. Upshaw v. United States, .335 U.S. 410, 413 (1948); United States v. Mitchell, 322 U.S. 65, 68, 70 (1944).

9. Brown v. Allen, 344 U.S. 443, 476 (1953) ; Gallegos v. Nebraska, 342 U.S. 55, $63-64$ (1951) ; McNabb v. United States, 318 U.S. 332, 340 (1943).

As a rule of federal criminal administration, the $M c N a b b$ rule does not apply to state criminal prosecutions. Brown v. Allen, supra; Gallegos v. Nebraska, supra; Stroble v. California, 343 U.S. 181, 197 (1952). 
The need to formulate a different analysis for $M c N a b b$ subsequent confession cases ${ }^{10}$ is revealed by two recent District of Columbia decisions. In Jackson v. United States, ${ }^{11}$ a post-arraignment confession was invalidated by the appellate court. Jackson was arrested at 5:00 a.m. He was incarcerated at 6:00 a.m., and, shortly afterward, was questioned by a detective for approximately one half hour. Beginning at 1:30 p.m. he was further questioned until, one hour and twenty minutes later, he made admissions of guilt. ${ }^{12}$ Immediately thereafter the United States Attorney's office was informed that Jackson had confessed, and he was promptly arraigned. At the arraignment, the accused was informed of his right to remain silent. He was then taken back to the offices of the robbery squad where, one half hour after arraignment, he signed a written confession prepared on the basis of his earlier oral admissions. At trial the oral admissions of guilt were ruled inadmissible because of the delay in arraignment; but the trial court permitted the introduction of the subsequent written confessions. The defendant was found guilty. On appeal, the circuit court reversed, stating:

Jackson's signing of the document cannot in any way be considered an independent act based upon proper counsel or as occurring after time for deliberate reflection. Rather the signature was obtained as a result of a purposeful process of inquiry undertaken during a period of unlawful detention. ${ }^{13}$

In Goldsmith v. United States, ${ }^{14}$ the admissibility of the defendants' postarraignment admissions ${ }^{15}$ was affirmed by the appellate court. Appellants

10. Cases dealing with the admissibility of subsequent confessions under $M c c N a b b$ have not dealt with the broad issue. Post-arraignment confessions following a confession made during illegal delay prior to arraignment were rejected in Trilling v. United States, 260 F.2d 677 (D.C. Cir. 1958) because the arraignment procedure was defective. Id. at 694-95 (concurring opinion).

A voluntary confession made after prompt arraignment is admissible. McNabb v. United States, 142 F.2d 904 (6th Cir. 1944), cert. denied, 323 U.S. 771 (1944) (second case). Delay in arraignment following a voluntary confession will not result in exclusion when the confession was made immediately after arrest, before the time for prompt arraignment had elapsed. United States v. Mitchell, 322 U.S. 65 (1944). A confession made after prompt arraignment for a crime other than the one for which the suspect had been arraigned is admissible, even though arraignment for the second crime was unduly delayed. United States v. Carignan, 342 U.S. 36 (1951).

11. 273 F.2d 521 (D.C. Cir. 1959) (per curiam).

12. Although the court referred to the statements made at this time as "admissions," it made no attempt to distinguish them from confessions and apparently thought of them as such. The police must have viewed the statements as confessions since they notified the United-States Attorney's Office that "Jackson had confessed." 273 F.2d at 522.

13. Id. at 523 .

14. 277 F.2d 335 (D.C. Cir. 1960).

15. Although the court referred to the post-arraignment statements as "admissions," it treated them as confessions and did not attempt to base its decision on a distinction between admissions and confessions.

"[A]dmissions [other] than those which directly touch the fact of guilt are without the scope of the peculiar rules affecting the use of confessions ...." 3 WIGMORE § 821, 
Goldsmith and Carter were arrested at $12: 30$ p.m. Interrogation commenced at $1: 30$, and at approximately $4: 35$ a written confession was signed. ${ }^{16}$ At $5: 00$ p.m. they were taken to the municipal court for arraignment, where they were given fifteen minutes to confer with court-appointed counsel, who advised them of their right to remain silent. After arraignment they were returned to the police station. There, after the police read their prior statement and asked whether the facts stated therein were true, they reaffirmed their previous confession. In addition, they engaged in a spontaneous colloquy with the complainant as to the amount of money which had been stolen, and re-enacted the crime. The trial court admitted the prearraignment written statement, not as a confession but as evidence of the post-arraignment admissions. It charged the jury that it was to consider these statements only if the subsequent re-affirmation were found to be voluntary. On appeal, the circuit court rejected the contention that the post-arraignment statements should be excluded as the fruit of illegal acts committed prior to arraignment, on the ground that there was no causal connection between the spontaneous colloquy with the complainant and the prior detention. The appellate court also rejected the argument that the post-arraignment confessions were involuntary, apparently holding that since the admissions were more than a mere mechanical restatement of the initial confession, they were voluntary. ${ }^{17}$

Neither opinion adequately discusses the possible effects which events during a period of unlawful detention may have upon subsequent confessions; both, therefore, fail to articulate all the factors which courts must consider when deciding whether to admit the second confession. In Jackson, the court did not explain whether it found the second confession invalid because

at 243; see Stein v. New York, 346 U.S. 156, 162 n.5 (1953). When statements contain the essential elements of a crime, they are regarded as confessions. See Opper v. United States, 348 U.S. 84, 91 (1954); Ashcraft v. Tennessee, 327 U.S. 274, 277-78 (1946) (second appeal); McCoRMrTck, Evidence $\$ 113$ (1954).

16. The majority opinion questioned the trial judge's finding that this confession was inadmissible under the Supreme Court's decision in Mallory v. United States, 354 U.S. 449 (1957), but found it unnecessary to make an independent determination of this question. 277 F.2d at $342-45$.

17. An appellate court is not bound by the trial court's determination that a confession was voluntary but may independently arrive at its own conclusion on the basis of the undisputed facts. See, e.g., Blackburn v. Alabama, 361 U.S. 199, 205 n.5 (1960) ; Spano v. New York, 360 U.S. 315, 316 (1959); Chambers v. Florida, 309 U.S. 227, 228-29 (1940). See also McCordick, Evidence $\$ 117$ (1954); 2 Wharton $\S 354$, at 52. The admission of a coerced confession at trial requires reversal by the appellate court even though there is additional evidence to support the conviction. See, e.g., Blackburn v. Alabama, supra at 206; Spano v. New York, supra at 324; Payne v. Arkansas, 356 U.S. $560,567-68$ (1958). The admission of evidence obtained in violation of Rule 5(a) which establishes the defendant's guilt is reversible error. Watson v. United States, 234 F.2d 42, 48 (D.C. Cir. 1956). There is disagreement as to the necessity for reversal if a wrongfully secured confession was relatively insignificant in establishing the defendant's guilt. Compare Watson v. United States, supra, with Comment, 68 YALE L.J. 1003, 1017 \& nn.93-94 (1959) (collecting authorities). 
it was involuntary, or because it was the "result" of an illegal act; if the latter reason was dispositive, its opinion does not reveal how one confession can be said to be the "result" of an earlier one. The Goldsmith opinion, although recognizing that a subsequent confession might have been tainted on both grounds, also failed to explain how illegal detention brings about either defect. A proper approach to $M c N a b b$ subsequent confessions requires further analysis into the several effects which illegal detention can have upon the mind of the accused, and the reasons for which these psychological effects may or may not offend the policies of the $M c N a b b$ rule.

One effect may be that the accused, having once confessed, will labor under a psychological disadvantage in later questioning. He will find it more difficult to face his interrogators, ${ }^{18}$ and he may reason that there is nothing to lose by confessing again. ${ }^{19}$ In United States $v$. Bayer, ${ }^{20}$ the Supreme Court recognized the existence of this pressure to confess again, commenting that once the accused has let the cat out of the bag, "he can never get the cat back in the bag."21 Although the confession in that case was admitted, the Court implied that for a limited time and under certain circumstances, this psychological disadvantage might itself disable a subsequent confession as "fruit of the poisonous tree."22 Exclusion on this ground seems a proper extension of the

18. See United States v. Bayer, 331 U.S. 532, 540 (1947) ("the secret is out for good"). See also, Malinski v. New York, 324 U.S. 401, 428 (1945) (Rutledge, J., separate opinion).

19. See Porter v. State, 55 Ala. 95, 106 (1876); People v. Jones, 24 Cal. 2d 601, 609, 150 P.2d 801, 805 (1944); Flamme v. State, 171 Wis. 501, 506, 177 N.W. 596, 598 (1920).

20. 331 U.S. 532 (1947).

21. Id. at 540 .

22. This inference is drawn from the Court's statement, per Justice Jackson:

In ... a sense, a later confession always may be looked upon as fruit of the first. But this Court has never gone so far as to hold that making a confession under circumstances which preclude its use, perpetually disables the confessor from making a usable one after these conditions have been removed.

331 U.S. at 540-41. (Emphasis added.) Other commentators have reached the opposite conclusion, see 26 TeXAs L. Rev. 536 (1948) ; Note, 33 Iowa L. Rev. 136, 139 (1947), apparently relying on Jackson's statement that the "fruit of the poisonous tree" cases "do not control this question," 331 U.S. at 541. In context, however, that statement seems only to say that the subsequent confession in this case was not the fruit of the first.

The phrase "fruit of the poisonous tree" was first employed by Mr. Justice Frankfurter in Nardone v. United States, 308 U.S. 338, 341 (1939), and refers to the doctrine excluding not only evidence directly obtained by an illegal act, but also any evidence obtained as a consequence of the act. See also Silverthorne Lumber Co. v. United States, 251 U.S. 385 (1920).

The issue of the admissibility of the "fruits" of an inadmissible confession has not yet been decided by a federal court. Commentators and almost all state courts hold such evidence admissible. See 2 Wharton $\S 358 ; 3$ Wigmore $\S 859$, e.g., State v. Turner, 82 Kan. 787, 794, 109 Pac. 654, 657 (1910); Harris v. Commonwealth, 301 Ky. \$18, 193 S.W.2d 466 (1946) ; State v. Lowry, 170 N.C. 730, 87 S.E. 62 (1915); State v. Cocklin, 109 Vt. 207, 194 Atl. 378, 380 (1937): But see Whitley v. State, 78 Miss. 255, 28 So. 
policies underlying the $M c N a b b$ rule. That rule seeks to discourage illegal detention tactics by not allowing prosecutors to use the product of such activity. ${ }^{23}$ If having the first confession has materially aided ${ }^{24}$ police in getting a second, and the second confession can be admitted in evidence, the deterrent effect achieved by excluding the first confession is dissipated. Thus, even if the second confession is voluntary, it should be excluded to discourage the unlawful procedures by which it was obtained. This rationale may have been the basis of decision in Jackson. Although the court's explanation-that defendant's post-arraignment signature "was obtained as a result of" questioning during his unlawful detention - can be interpreted as a finding of involuntariness, it may simply mean that, voluntary or not, the signature was the product of an illegal act.

The Supreme Court has recognized, however, that the first confession cannot "perpetually" disable the defendant from making a valid confession. ${ }^{25}$ In United States v. Bayer, the Court refused to exclude a confession made six months after the first confession. ${ }^{26}$ Therefore, courts evaluating a subsequent confession apparently must distinguish between cases in which the psychological disadvantage of having made the first confession has contributed significantly to the second confession, and those cases in which the disadvantage has been neutralized. The Bayer case offers no guides for making this decision,

852 (1900). Only one federal case was found involving this issue, United States v. Montalvo, 271 F.2d 922, 926-27 (2d Cir. 1959), but failure to raise a timely objection at trial precluded the defendant from raising the issue on appeal. In light of the similarity of this question to the problems presented by Silverthorne and Nardone the Supreme Court would probably require the exclusion of evidence so obtained in a federal criminal trial. Cf. Stein v. New York, 346 U.S. 156, 203 (1953) (dissenting opinion); Scott, Federal Control Over Use of Coerced Confessions in State Criminal Cases-Some Unsettled Problems, 29 IND. L.J. 151, 156-57 (1954). But see Note, 47 CoLUM. L. Rev. 1214, 1218 (1947).

23. See cases cited note 9 supra.

24. Both Nardone and Silverthorne agree that if the evidence in question had been secured independently of the illegally obtained evidence, it would be admissible. 308 U.S. at $341 ; 251$ U.S. at 92 . The "fruit of the poisonous tree" doctrine, therefore, seems to exclude only evidence which was a direct consequence of the evidence illegally obtained. See 26 Texas L. Rev. 536, 536-37 (1948). If this distinction were applied to subsequent confessions as "fruits" of earlier confessions, however, no subsequent confession would be able to meet the test; the complex factors which motivate a confession preclude any clean separation between "independent" confessions and those directly traceable to earlier ones.

This distinction, however, may not be an essential part of the doctrine, but rather a characteristic of the evidence to which the doctrine was applied in those cases. Moreover, if the purpose of the doctrine is to deter illegal conduct by depriving police of the benefit of such conduct, the rule ought not to be limited to cases of "but for" benefit. Therefore, a more realistic approach would require, admittedly without precision, only that the first confession be a significant aid in eliciting the second.

25. 331 U.S. at 541.

26. Ibid. 
apart from suggesting a broad consideration of the circumstances surrounding the subsequent confession, particularly the lapse of time. ${ }^{27}$

A more objective test has been proposed by some commentors: the second confession should be admissible only when the accused has been advised that his prior confession cannot be used against him. ${ }^{28}$ This proposal seeks to counteract one of the most important consequences of having made a confession - the accused's belief that a second confession will be harmless because his case has already been lost. ${ }^{29}$ This specific proposal is probably unworkable, because committing magistrates are not authorized to make a final determination of admissibility ${ }^{30}$ moreover, police officers will be reluctant to declare their own prior conduct unlawful. ${ }^{\mathbf{3 1}}$ But the same safeguard might be achieved by requiring, as standard procedure, that either the committing magistrate or the police advise every defendant that confessions made before arraignment are not necessarily admissible in court. ${ }^{32}$ Compliance with this procedure probably should not be made a per se condition of admissibility, to the exclusion of other mitigating factors; but the presence or absence of such a warning to the defendant could weigh heavily in the court's assessment of the psychological handicap of the first confession. Admittedly, even the most effective warning could not entirely remove the handicap, for the defendant must still face police officials in subsequent interrogation knowing that he has once confessed to them. This pressure can never be erased. But the Supreme Court's decision to admit the second confession in Bayer, despite the acknowledged continuance of this disadvantage, ${ }^{33}$ indicates that it alone is not sufficient to void a second confession.

If coercive police methods or false promises were used during the period of detention, a second effect of illegal detention may be the continued influence of these tactics upon the defendant's mind. ${ }^{34}$ Although the invalidation of a

27. The court noted that the defendant had not been in close confinement during this period. Ibid.

28. McCormick, Evidence § 114, at 237 (1954) ; 26 Texas L. Rev. 536, 538 (1948); cf. 33 Iowa L. Rev. 137 (1947).

29. See cases cited note 19 supra.

30. Admissibility is for the trial court to determine, see Morgan, Maguire \& WEINstern, Cases on Evidence 725 n.11 (4th ed. 1957); McCoratck, Evidence $\$ 112$ (1954); 2 WHARTON $\$ 351$, and even this determination may be reviewed on appeal, see note 17 supra. Moreover, the commissioner does not inquire into the question of illegal detention; even if he did, the complexity of the admissibility decision, see Comment, 68 YALE L.J. 1003, 1007-09 (1959), would seem to preclude an authoritative decision at this level.

31. See McCormick, Evidence $\$ 112$ (1954).

32. But cf. Biderman, Social Psychological Needs and "Involuntary Behavior" as Illustrated by Compliance in Interrogation, 23 Socrometry 120, 121 (1960) (Prisoners of war instructed to divulge no information except name, rank, or serial number "rarely conform to this injunction of silence in interrogation because to do so is inconsistent with more compelling requirements they experience in the actual situation; namely, the maintenance of a viable social role and an esteemed self-image.").

33. 331 U.S. at $540-41$.

34. See, e.g., Lyons v. Oklahoma, 322 U.S. 596, 602 (1944); Jackson v. State, 209 Md. 390, 396, 121 A.2d 242, 245 (1956). 
prearraignment confession under the $M c N a b b$ rule does not depend upon a specific finding of involuntariness, this fact should not preclude courts, when they examine a subsequent confession, from considering the possibility that the defendant was motivated by fear of coercion or continued false hopes.

Before the continued influence of third degree methods can be found, however, the court must first establish that such methods were employed during the period of delay. Since invalidation of the first confession under the per se $M c N a b b$ rule does not itself prove coercion, ${ }^{35}$ the court might require the defendant to bring forward evidence of the prior coercion before allowing him to attack the subsequent confession on this ground. Proof of such conduct can be very difficult, however, because even though the government bears the ultimate burden of proof, ${ }^{36}$ a defendant questioned incommunicado often must rely solely on his own allegations of duress. ${ }^{37}$ For this reason, the fact that defendant confessed during illegal detention might be used to create a presumption that third degree tactics were used. ${ }^{38}$ This extension of the $M c N a b b$ rule would increase considerably the penalty imposed upon police for illegal detention; in addition to losing the first confession, they could not use a post-arraignment confession without first satisfying the court that it was freely made. Before creating this presumption, therefore, courts must be satisfied that increasing the burden on the police is necessary to maintain the standards announced in $M c N a b b$. This judgment turns on the relationship between illegal detention and police coercion. $M c N a b b$ and the cases applying $M c N a b b$ have recognized that coercion is a likely concomitant of illegal detention. ${ }^{39}$ Given this probability, the presumption might be justified if the difficulty of proving prearraignment coercion would prevent successful attack on the admissibility of involuntary second confessions in a large number of cases. Although the argument for adding this presumption is stated only in probabilities, probabilities are relevant materials for decision when, as in $M c N a b b$, federal rules of evidence are being used to maintain general standards of police conduct which are themselves based upon probabilities of abuse. ${ }^{40}$

35. See notes 7-8 supra and accompanying text.

36. Once the defendant raises the coercion issue the burden of proving the confession was voluntary rests on the government. See United States v. Echeles, 222 F.2d 144 (7th Cir. 1955) ; Patterson v. United States, 183 F.2d 687, 689-90 (5th Cir. 1950). Most state jurisdictions seem to be in accord. See Morgan, McGurre \& Wernstein, Cases on EVIDENCE 722 n.9 (4th ed. 1957).

37. For an extended discussion of the defendant's disabilities in successfully asserting the coercion issue, see Note, 66 Y ALE L.J. 270, 278, n.33 (1956).

38. One commentator has suggested that $M c N a b b$ itself is based upon such a presumption. Note, 66 YaLE L.J. 270, 279 (1956).

39. See cases cited note 6 supra. See also American Civil Liberties Union, Illinors Division, Secret Detention by the Chicago Police (1959); A Memorandum on the Detention of Arrested Persons Accompanying a Statement by the Comamtree on the Bill of Rights of the AMrerican Bar Association on H.R. 3690 (1944); 11 Nat' Comms'n on Law Observance and Enforcement, Report (1931); Hopkins, Our Lawless Police (1931).

40. See, e.g., the statements quoted in note 6 supra; Brown v. Allen, 344 U.S. 443, 476 (1953). 
Once it has been established that the first confession was not voluntary, either by proof or by presumption, the court must then decide whether the state of mind induced by third degree tactics has continued and has influenced the confession. In the case of a proven coerced confession, the government is required to overcome a presumption that the influence of its earlier conduct has continued. ${ }^{41}$ But if prior coercion itself has been established by another presumption, use of the presumption of continuance may go too far. Perhaps in this case the defendant should be required to prove that his second confession was not voluntary.

Courts have traditionally considered five major criteria in deciding whether a subsequent confession is voluntary. First, a court will look at the elapsed time between the two confessions, on the assumption that a coerced suspect's inclination to confess will diminish over time. ${ }^{42}$ Second, outward manifestations of volition exhibited by the defendant at the time he made the second confession will be scrutinized, including the degree of spontaneity displayed, ${ }^{43}$ the disclosure of material not part of the first confession, ${ }^{44}$ and the absence of persons who participated in the coercion. ${ }^{45}$ Third, any spontaneous admissions made by the suspect after the second confession will be weighed. ${ }^{46}$ Fourth, the court will consider the defendant's position in his community, ${ }^{47}$ his age, ${ }^{48}$ and his intelligence ${ }^{49}$ to determine whether any advice given to him prior to the

41. See note 3 supra.

42. Compare Leyra v. Denno, 347 U.S. 556, 561 (1954), with Lyons v. Oklahoma, 322 U.S. 596, 604-05 (1944). See United States v. Gottfried, 165 F.2d 360, 366-67 (2d Cir. 1948) (L. Hand, J.). Compare Lang v. State, 178 Wis. 114, 189 N.W. 558 (1922) (one day interval), with State v. Chambers, 39 Iowa 179, 183 (1874) (ten month delay). For a general discussion of the psychological effect of passage of time upon acceptance by an individual of a position taken by a communicator, see HovLAND, JANIs \& KELLEY, Communication and Persuasion 253-65 (1953).

43. See, e.g., Lyons v. Oklahoma, 322 U.S. 596, 604-05 (1944) ; Stroble v. California, 343 U.S. 181, 191 (1952); State v. Chiasson, 174 La. 542, 141 So. 54 (1932).

44. See Lyons v. Oklahoma, 322 U.S. 596, 604-05 (1944) ; United States v. Gottfried, 165 F.2d 360, 366 (2d Cir. 1948).

45. See, e.g., State v. Chaves, 27 N.M. 504, 507, 202 Pac. 694, 695 (1921); State v. Hamer, 240 N.C. 85, 86, 81 S.E.2d 193, 194 (1954); cf. Whitley v. State, 78 Miss. 255, 258, 28 So. 852, 853 (1900); State v. Ellis, 294 Mo. 269, 283, 242 S.W. 952, 955 (1922). The presence at the time of the second confession of individuals who participated in prior coercion is taken into consideration. See, e.g., Jackson v. State, 209 Md. 390, 395, 121 A.2d 242, 245 (1956) ; Lang v. State, 178 Wis. 114, 125, 189 N.W. 558, 563 (1922).

46. Lyons v. Oklahoma, 322 U.S. 596, 605 (1944) (conversation with prison guard); Burwell v. Teets, 245 F.2d 154, 162 (9th Cir. 1957) (conversation with prison doctor); cf. Leyra v. Denno, 347 U.S. 556, 561 (1954).

47. Polk v. State, 170 Tenn. 270, 275, 94 S.W.2d 394, 396 (1936) ("ignorant negroes") ; cf. Lang v. State, 178 Wis. 114, 127, 189 N.W. 558, 563 (1922) ("weak morally, intellectually, and physically . . . sadly addicted to drink").

48. United States v. Cooper, 25 Fed. Cas. 629, 631 (No. 14863) (D. Va. 1857) (ffifteen year old defendant); People v. Jones, 24 Cal. 2d 601, 609, 150 P.2d 801, 805 (1944) (seventeen year old defendant).

49. Porter v. State, 55 Ala. 95, 106 (1876) ("the prisoner was evidently an ignorant man"); Walker v. State, 7 Tex. Ct. App. R. 245, 262-63 (1879); cf. Burwell v. Teets, 
second confession-either by the magistrate at arraignment, by police officials, or by counsel-was understood. Fifth, courts normally inquire into the type and extent of the initial coercion. ${ }^{50}$ This fifth criterion cannot be used, of course, if coercion is merely presumed and defendant cannot prove what methods were in fact used. If consideration of all these factors indicates that the second confession is involuntary, it can be excluded either as a violation of due process or, under $M c N a b b$, as a product of the illegal act of detention.

Analyzed in terms of these factors, both Jackson and Goldsmith correctly decide the fear-of-coercion issue. In Goldsmith, the opportunity to consult with counsel and the subsequent spontaneous reaffirmation and reenactment of the crime suggest that the state of mind induced by the illegal delay had been dissipated, notwithstanding the short time period between the acknowledgments of guilt and the continuous confinement. In Jackson, on the other hand, the short time period, the absence of consultation with counsel, and particularly the mechanical nature of the reacknowledgment suggest that, if there had been coercion initially, fear of renewed coercion would probably have influenced the second confession.

A third possible effect of illegal detention is the possibility that the act of making the initial confession will distort an innocent suspect's view of the truth, and that later confessions, although freely given, will not be trustworthy. Recent psychological studies reveal that encouraging a person to adopt a position at variance with his privately held opinion will sometimes change his private opinion to bring it into conformity with induced belief-the theory of "cognitive dissonance." 51 Of course, the present level of psychiatric knowledge may not be sufficient to produce persuasive evidence warranting exclusion of a subsequent confession on this ground. Nevertheless, courts should recognize the existence of this phenomenon; if its effect can be proven in a particular case, both the $M c N a b b$ rule and the due process clause would compel invalidation of the resulting confession.

245 F.2d 154, 160 (9th Cir. 1947) ("more than ordinary intelligence"); Lang v. State, 178 Wis. 114, 127, 189 N.W. 558, 563 (1922) ("weak . . . intellectually").

50. Leyra v. Denno, 347 U.S. 556, 561 (1954) (psychiatric trance); United States v. Gottfried, 165 F.2d 360, 366-67 (2d Cir. 1948) (threatened with a denial of parole and a change of prisons) ; People v. Jones, 24 Cal. 2d 601, 609, 150 P.2d 801, 805 (1944); State v. Chambers, 39 Iowa 179, 183 (1874) (assurance of friendship and promises); Jackson v. State, 209 Md. 390, 395, 121 A.2d 242, 244-45 (1956) (physical violence); State v. Ellis, 294 Mo. 269, 283, 242 S.W. 952, 955 (1922).

51. Festinger, A Theory of Cogntrive Dissonance 4-6, 95, 112 (1957) ; Festinger, Ricken \& Schachter, When Prophecy Fails 25-27, $228-29$ (1956) ; Hovland, Janis \& Keldey, Communication and Persuasion 127 (1953); Cohen, Brehm \& Flemming, Attitude Change and Justification for Compliance, 56 J. AB. \& Soc. Psy. 276 (1958) ; cf. Meerloo, Rape of The Mind 27-31 (1956). 